\title{
THE STRUCTURE OF NEARSHORE CURRENTS DRIVEN BY CHANGES IN METEO-MARINE FORCINGS
}

\author{
Petitjean L. ${ }^{1}$, Sous D. ${ }^{1}$, Rey V. ${ }^{1}$, Bouchette F. ${ }^{2}$, Sabatier F. ${ }^{3}$, Meulé S. ${ }^{3}$
}

\begin{abstract}
This work aims to better understand the physical processes governing the wave propagation in a vertically sheared current and the resulting nearshore circulation patterns. It is based on a high resolution hydro-morphodynamic field campaign, ROUSTY2014, collecting a comprehensive hydro-morphodynamical dataset during a full winter season. The overall analysis highlights three main circulation patterns, largely controled by the bathymetric features and by co-working or competing wind and waves forcings. Regarding the vertical structuration of the circulation, most of field observations shown seaward directed circulation with onshore component close to the air/sea surface whose intensity varies according to incoming wave conditions. Forth, vertical shear increase when breaking happen close to sensor location and orientation of mean circulation depend on wind direction.
\end{abstract}

Keywords: nearshore circulation, microtidal barred beach, vertical velocity structure

\section{INTRODUCTION}

In coastal sciences, the nearshore circulation is of primary importance for a number of physical and biogeochemical processes such as the mixing and the renewal of coastal waters, the transport of contaminants and pollutants or the beach sediment transport. The main forcings of the nearshore circulation are the tide excursion, the waves, the wind, the regional buoyancy circulation and the terrestrial inputs. The role of breaking waves in driving strong longshore currents has early been recognized by field and modelling studies (Longuet-Higgins, 1970; Thornton, 1970), as well as the strong topo-bathymetric control on the structuration of alongshore patterns (O'Rourke and LeBlond, 1972; Thornton and Guza, 1986; Larson and Kraus, 1991). For the sake of computational efficiency, nearshore currents are often depth-averaged in numerous numerical models of nearshore hydro- and morphodynamics. This assumption is widely used even though the knowledge of the vertical structuration of the current is of great importance for mixing, sediment transport or wave propagation. The vertical structure of nearshore currents has been studied already by means of laboratory experiments (e.g. Hansen and Svendsen, 1985; Okayasu et al., 1989; Ting and Kirby, 1994), field studies (e.g. Greenwood and Osborne, 1990; Putrevu and Svendsen, 1993; Faria et al., 2000; Feddersen and Guza, 2003; Reniers et al., 2004) or various models (e.g. Cox and Kobayashi, 1998; Reniers et al., 2004). However, there is an incomplete characterization of such a vertical structuration by means of in-situ data.

The overall trend is that longshore currents show a weakly sheared profile outside the wave boundary layer, closely corresponding to a standard log profile. The vertical homogeneity is increased in the presence of wave breaking, which enhances mixing and momentum transfer in the water column (Church and Thornton, 1993). Cross-shore currents generally exhibit much stronger vertical shear, mainly due to the imbalance between wave force and cross-shore horizontal pressure gradient (Dyhr-Nielsen and Sørensen, 1970). Despite of great research efforts spent in the last four decades, the determination of generic vertical profile of cross-shore velocity is still an open question with significant differences observed between laboratory and field studies. The actual understanding is that, in the surf zone, the vertical shear is greater near the surface due to the action of breaking wave at the surface (Stive and Wind, 1986). The overall setup pressure gradient is compensated by a return flow lower in the water column, eventually down into the bottom boundary layer (e.g. Haines and Sallenger, 1994). By contrast, in the absence of wave-breaking, an onshore flow is expected near the bottom. The wind effect is essentially similar to the wave breaking one but often much weaker (Whitford and Thornton, 1993). However, the wind action on nearshore current vertical structure remains poorly documented, in particular when considering wind and waves from opposite directions.

The aim of the present study is to provide and to analyze a seasonal data set of vertical velocity profiles along a nearshore cross-shore transect. A particular attention is paid to the response of both horizontal and vertical flow structures to the combined evolution of external forcings.

\footnotetext{
${ }^{1}$ Université de Toulon, Aix Marseille Université, CNRS, IRD, Mediterranean Institute of Oceanography (MIO), La Garde, France

${ }^{2}$ GEOSCIENCES-Montpellier, Université de Montpellier II, Montpellier, France

${ }^{3}$ CEREGE, Aix-Marseille Université, CNRS UMR 6635, Aix en Provence, France
} 


\section{FIELD SITE AND EXPERIMENTAL SETUP}

\section{Rousty beach}

The studied site is the microtidal Rousty beach located on the Mediterranean coast of France in the National park of Camargue. Hydro- and morphodynamics features of Rousty sand beach have been monitored for 15 years (see Sabatier, 2001, 2008; Sabatier et al., 2009a,b; Ouahsine et al., 2013). Fig. 1 shows a profile of Rousty beach with a typical fair weather swash bar below the berm. The profile measured during the experiment has been smoothed by the winter wave climate (Fig. 2). A nearshore bar (Fig. 2) may occur at several locations from $X=105 \mathrm{~m}(Z=-0.1 \mathrm{~m})$ to $X=140 \mathrm{~m}(\mathrm{Z}=-0.6 \mathrm{~m})$ in the local datum (see below for details). The mean sediment size is around $200 \mu \mathrm{m}$, with a tendency for coarser grains close to the shoreline. The tide range is small (around $0.3 \mathrm{~m}$ ). However, the mean water level shows significant fluctuations, rising to more than $1 \mathrm{~m}$ under South-Easterly wind and low atmopheric pressure conditions associated with storms striking the northern Gulf of Lions. Setdown can reach $-0.5 \mathrm{~m}$ during Northerly (Mistral), North-Westerly (Tramontane) winds and concommitant high pressure conditions.
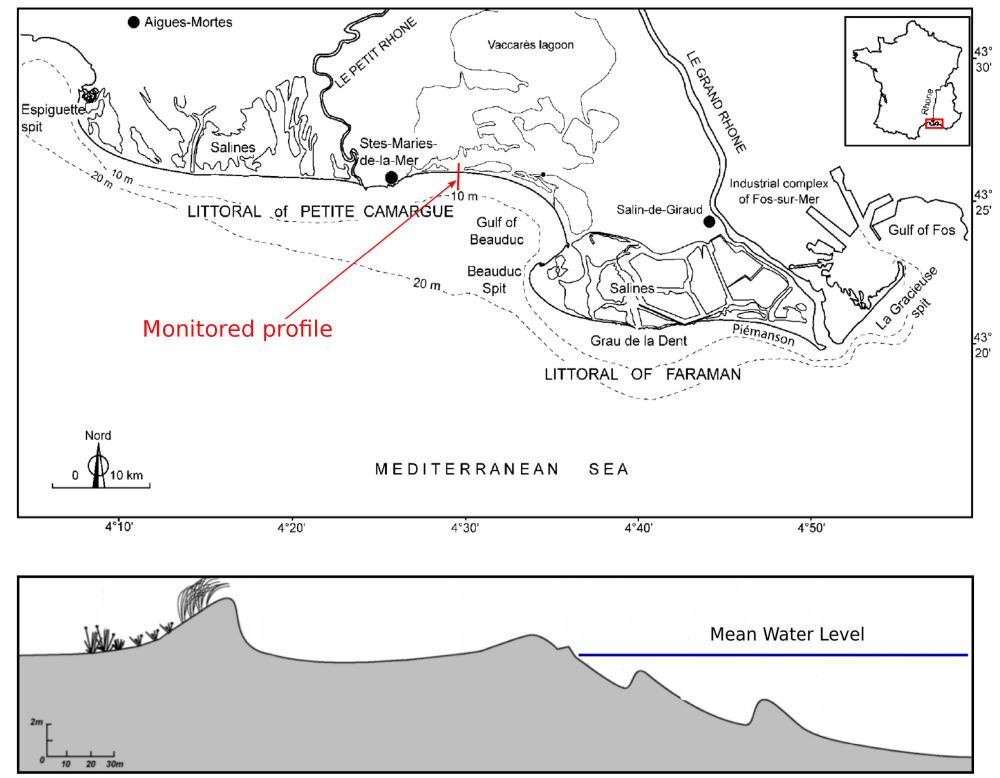

Figure 1: Site location and typical beach profile (from Sabatier, 2001).
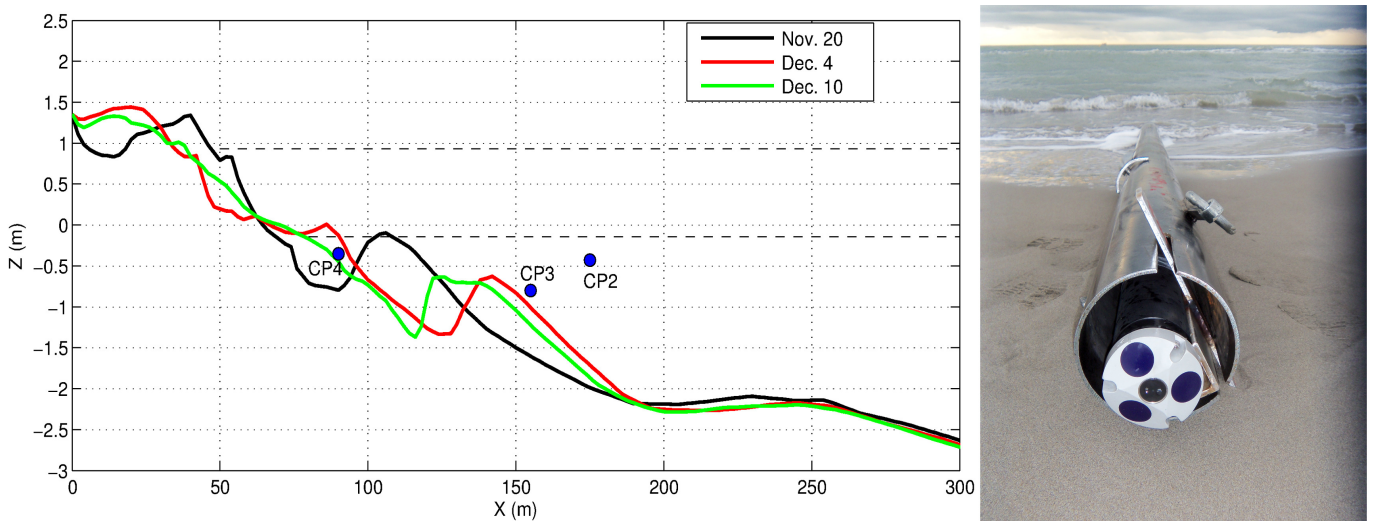

Figure 2: Experimental setup. Left: current profilers location (with beach profiles on Nov. 20, Dec. 4 and Dec. 10). Black dashed lines represent the minimal and maximal still water levels measured during the experiment. Right: a current profiler (Nortek Aquadopp ${ }^{\circledR}$ ) before its deployment, embedded in a 6 m long steel tube. 


\section{Instrumentation and methods}

During the ROUSTY2014 field experiment, a sizeable network of instruments has been deployed for three months from November 2014 to February 2015 to characterize the hydro-morphodynamical beach processes during the winter season. The present study focuses on the data provided by four current profilers deployed at fixed positions along a single cross-shore transect. The setup of the equipments has been designed to face the severe hydrodynamic conditions occasionally encountered during winter season in the Gulf of Lions. Each current profiler is embedded in a 4 to $6 \mathrm{~m}$ long steel tube deeply buried in the sand (see Fig. 2 for a view at a mounting device before deployment). As both bed position and sea level continously evolve during the acquisition period, the portion of the water column actually described by the current profilers changes with time (CP4 was buried for few hours around Dec. 4). Lower shoreface hydrodynamics are measured by the $\mathrm{CP} 1$ profiler $\left(\mathrm{RDI} \mathrm{ADCP}^{\circledR}\right.$ ) deployed in about $6 \mathrm{~m}$ water depth, 700 $\mathrm{m}$ off the shoreline. Hydrodynamics over the lee side of the outer bar are described by the CP2 and CP3 profilers (Nortek Aquadopp ${ }^{\circledR}$ ) while measurements in the trough and over the lee side of the outer are performed by the CP4 profiler (Nortek Aquadopp ${ }^{\circledR}$ ), see Fig. 2 for profiler positions. The minimal and maximal still water levels observed during the experiment are depicted in black dashed lines in Fig. 2 to document the relative position of the instruments within the water column. The following analysis is carried out on time-averaged horizontal velocity over 1h30, i.e. 9 bursts of $1 \mathrm{~min}$ at $2 \mathrm{~Hz}$ each $10 \mathrm{~min}$, except for CP4 limited to 4-5 burst of $20 \mathrm{~min}$ each. Cell sizes are $0.2 \mathrm{~m}$ high for CP1 and $0.1 \mathrm{~m} \mathrm{for} \mathrm{CP2,} \mathrm{CP3} \mathrm{and}$ CP4. Regular topo-bathymetric surveys have been conducted during the experiment with RTK-DGPS and tacheometer. Beach profiles measured on Nov. 20, Dec. 4 and Dec. 10 are shown in Fig. 2.

\section{Weather conditions and wind-wave climates}

The time series of wind and wave conditions that occurred during the experiment are plotted in Fig. 3. Wind measurements over the studied period are provided by the MétéoFrance Grau du Roi station. These regional wind regimes are usually divided into three main types: (i) so-called Northerly winds, blowing from North-West to North-East (namely Tramontane, Mistral and Grecale) and generally associated with dry weather, high atmospheric pressure and low sea level; (ii) South-Easterly winds (Marin, Autant or Levant) usually associated with storms or low pressure systems with higher sea levels and rainfalls; (iii) Westerly and South-Westerly winds (Albe or Libeccio).

During the winter 2014-2015, strong wind regimes with magnitude greater than $15 \mathrm{~m} / \mathrm{s}$ are observed for Northerly and South-Easterly winds mainly; Northerly and South-Easterly winds blow $45 \%$ and $12 \%$ of the time respectively. This distribution is unusual with respect to the mean trends recorded in the Gulf of Lions (Sabatier, 2001) showing more South-Easterly conditions. Incoming wave height are measured at the lower shoreface measurement point (CP1) in $6 \mathrm{~m}$ of water depth on a seabottom showing locally a very gentle and regular slope; wave conditions are thus deshoaled using the linear theory to reconstruct the deep water wave height $H_{o}$ in $20 \mathrm{~m}$ of water depth. Forth, the position of the breaking point is calculated using the criterion of Thornton and Guza (1983) applied to the wave shoaled along the beach profile from the closure water depth. Unfortunately, wave direction data are not available at the lower shoreface measurement point (CP1). Wave direction are then extracted further offshore from Wavewatch III PREVIMER numerical simulations and averaged over a zone whose upper left and bottom right coordinates are $\left(43^{\circ} 18^{\prime} \mathrm{N} ; 4^{\circ} 24^{\prime} \mathrm{E}\right)$ and $\left(43^{\circ} 24^{\prime} \mathrm{N} ; 4^{\circ} 33^{\prime} \mathrm{E}\right)$ respectively. The wave climate is rather bimodal (Fig. 3). The most frequent wave conditions (so-called fair weather waves) are short $\left(T_{p}<6 \mathrm{~s}\right)$, small $\left(0.5<H_{s}<1 \mathrm{~m}\right)$ with a dominant incoming direction from South-West. Storm waves are generated by South-East winds and have a typical Mediterranean signature $\left(H_{s}>2 \mathrm{~m}\right.$ and $\left.T_{p}>7 \mathrm{~s}\right)$. Due to the overall shoreline curvature (see Fig.1), the experimental site is affected by West to South-East waves mainly, accounting for refraction effects discussed later on.

\section{RESULTS: HORIZONTAL CURRENT FEATURES}

Time series for both cross- and longshore depth-averaged velocity components along our experimental cross-shore transects from the most offshore measurement point (CP1) to the trough measurement (CP4) are shown in Fig. 3. A first analysis is performed on the observations in terms of magnitude and direction, intersites relationships and response to the external forcings. Cross-shore depth-averaged horizontal velocities $(U)$ are positive shoreward while longshore horizontal velocity $(V)$ are positive westward. In the following $U$ and $V$ are referred to as current components. 

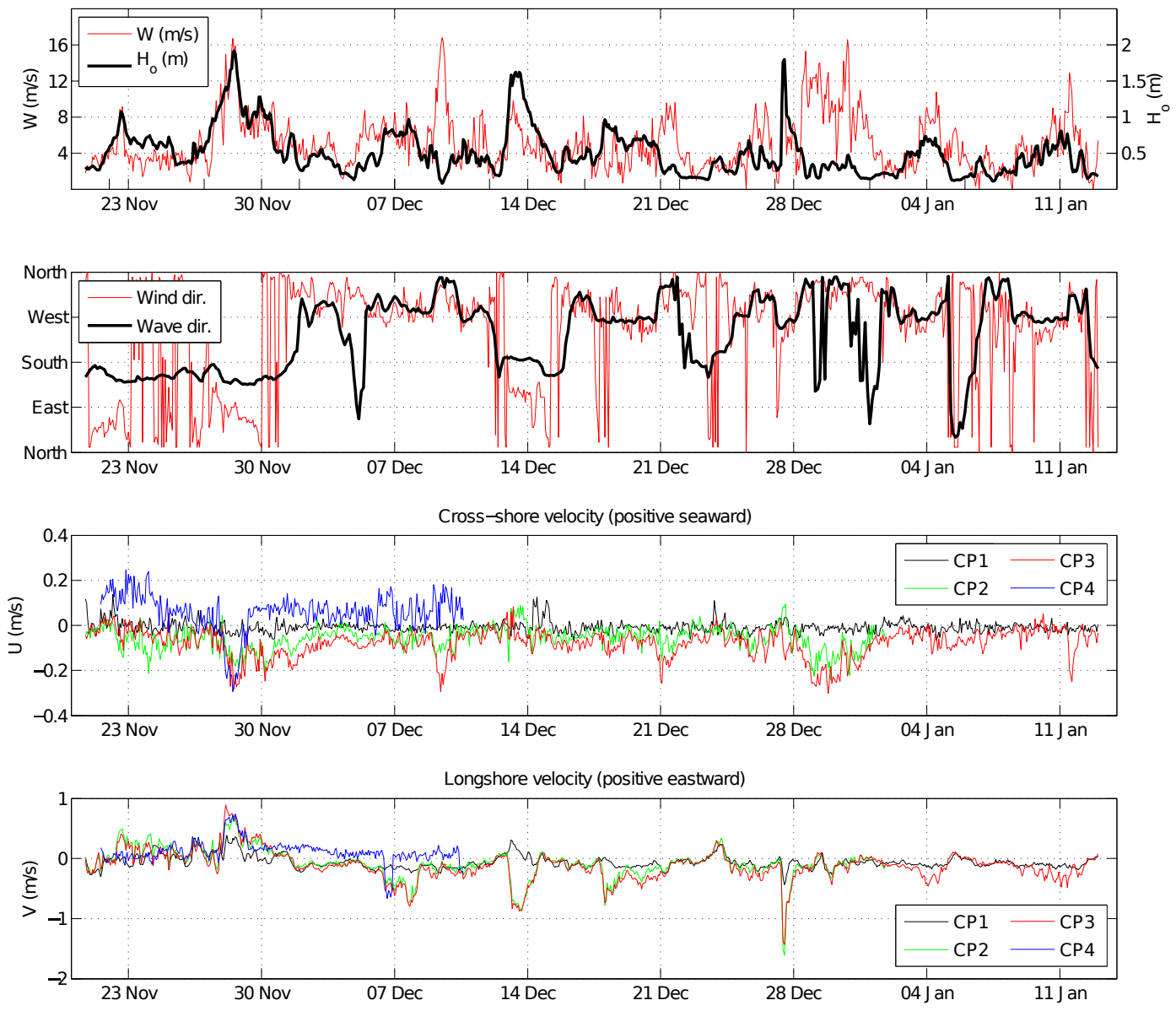

Figure 3: Time series for (a) incoming wave height and wind magnitude, (b) incoming wave direction and wind azimuth, (c) cross-shore $U$ and longshore $V$ components of the depth-averaged velocity at four monitored points (CP1, CP2, CP3, CP4) along the cross-shore profile.

\section{Circulation in the lower shoreface (CP1)}

The depth-averaged currents at the offshore measurement point (CP1) are depicted in black in Fig. 3. It is first recalled that whatever the wave conditions, the $\mathrm{CP} 1$ measurement point is located far beyond the surf zone. The mean currents are quite weak, about $-1 \mathrm{~cm} / \mathrm{s}$ (seaward) and $-6 \mathrm{~cm} / \mathrm{s}$ (eastward) for crossand longshore components respectively. The cross-shore component does not show any clear statistical relationship with the external forcings. The general trend for the longshore component is eastward (negative) during North-Westerly fair weather breeze, moderate swell, high atmopheric pressure and low sea level. Conversely, the longshore current is westward during low pressure conditions associated to waves and winds from the South-East. Obviously, currents are stronger (up to $0.5 \mathrm{~m} / \mathrm{s}$ ) when wave energy increases. They tend to be correlated with the wave breaking over the bar: when incoming wave height is large enough to produce wave breaking over the bar slope. Current direction is not directly related to incoming wave direction as shown in Fig. 4.

Storm swells from the East are generally associated with fast longshore westward currents but incoming western swells can be associated with either westward or eastward currents. Furthermore, on Dec. 25 during quite calm wind and wave conditions, significant westward currents are observed. A correct interpretation of such circulation patterns must consider the peculiar shoreline curvature to the West (Beauduc sand spit) combined with the presence of a steady westward coastal buoyancy current which can meander in the form of local coastal eddies (Petrenko, 2003; Petrenko et al., 2005; Leredde et al., 2007). 

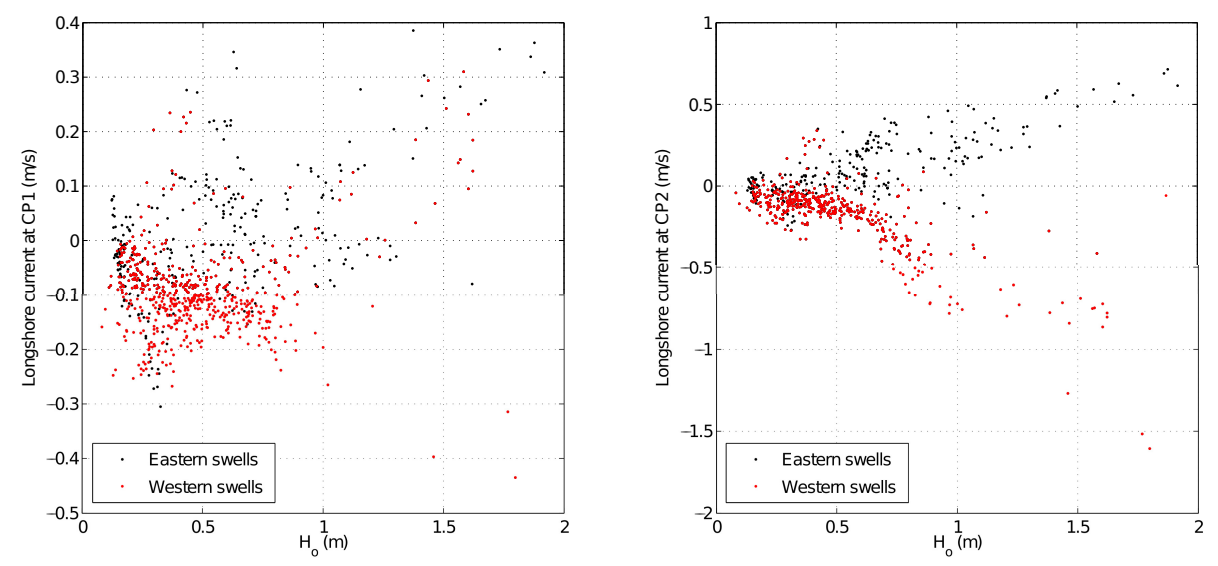

Figure 4: Depth-averaged longshore current at CP1 (left) and CP2 (right) versus deep water wave height.

\section{Circulation over the outer bar slope (CP2 and CP3)}

The first observation is the strong coupling between currents at CP2 and CP3: linear correlation coefficients reach $97 \%$ and $70 \%$ for longshore and cross-shore components, respectively whereas the same coefficients between $\mathrm{CP} 1$ and $\mathrm{CP} 2$ are 53 and 25\%. Currents are generally stronger closer to the bar with mean values for cross- and longshore currents about $-6 \mathrm{~cm} / \mathrm{s}$ and $-8 \mathrm{~cm} / \mathrm{s}$ for $\mathrm{CP} 2$, and $-8 \mathrm{~cm} / \mathrm{s}$ and -12 $\mathrm{cm} / \mathrm{s}$ for CP3. The longshore currents show a strong dependence to incoming wave height and direction, as illustrated in Fig. 4 for CP2 measurement (right plot). Observations at CP3 are in very good agreement. An overwhelming tendency much more defined than in the lower shoreface is that a swell from the South-East forces a westward longshore current while a swell from the West drives an eastward current. This expected behaviour appears as soon as the wave height is sufficient to localize the wave breaking on the bar. The current increase is observed at CP2 as soon as waves break on the bar, even though the surf zone does not extend up to this measurement point. When waves are large enough to break at CP2 (typically for $H_{o}>1$ $\mathrm{m})$, the magnitude of the current further increases, still shows the aforementioned bimodal wave-driven orientation, and reaches a maximal value about $1.5 \mathrm{~m} / \mathrm{s}$ (during a Westerly event). The cross-shore current over the bar slope is generally weaker than its longshore counterpart and nearly systematically seaward. The strongest values about $0.3 \mathrm{~m} / \mathrm{s}$ are obtained under two distinct conditions: storms from the South-East or strong Mistral Northerly waves.

\section{Circulation in the trough (CP4)}

In the trough, cross-shore currents are mostly positive (shoreward) with mean value about $6 \mathrm{~cm} / \mathrm{s}$. They are observed to reverse seaward and increase up to $0.3 \mathrm{~m} / \mathrm{s}$ during storm events. The longshore component is stronger, positive (westward) with a mean value of $11 \mathrm{~cm} / \mathrm{s}$, and increases up to $0.75 \mathrm{~m} / \mathrm{s}$ during storms from the South-East. This dominant trend reverses during western swells (see e.g. Dec. 6 in Fig. 3). The observations confirm a very classical circulation pattern: longshore currents in the trough are pushed by the offshore wave direction. However, the relationship between trough and bar slope currents is not that straigthforward. During calm conditions (see for instance the early days of December in Fig. 3), longshore currents are opposite in the trough and at the bar slope, being respectively westward and eastward. During wave events, currents can be either well linked, being both westward on Nov. 27 or eastward on Dec. 6 (Fig. 3), or can be decoupled as observed on Dec. 7-8 with strong eastward currents on the bar slope and nearly zero flow in the trough. This latter observation is very peculiar, as the vanishing of the longshore current in the trough is not related to any significant change of external forcings.

\section{RESULTS: VERTICAL STRUCTURATION OF THE NEARSHORE CIRCULATION}

The analysis of the vertical profiles reveals that longshore component of the current is generally more vertically uniform than cross-shore component, which is consistent with respect to the rare existing field observations (Smith et al., 1993a; Thornton et al., 1996; Reniers et al., 2004). To document the response of the vertical flow structure to the change in meteo-marine conditions, four typical configurations are analysed below; results are illustrated with day-averaged profiles (Fig. 5). As bed elevation and MWL 

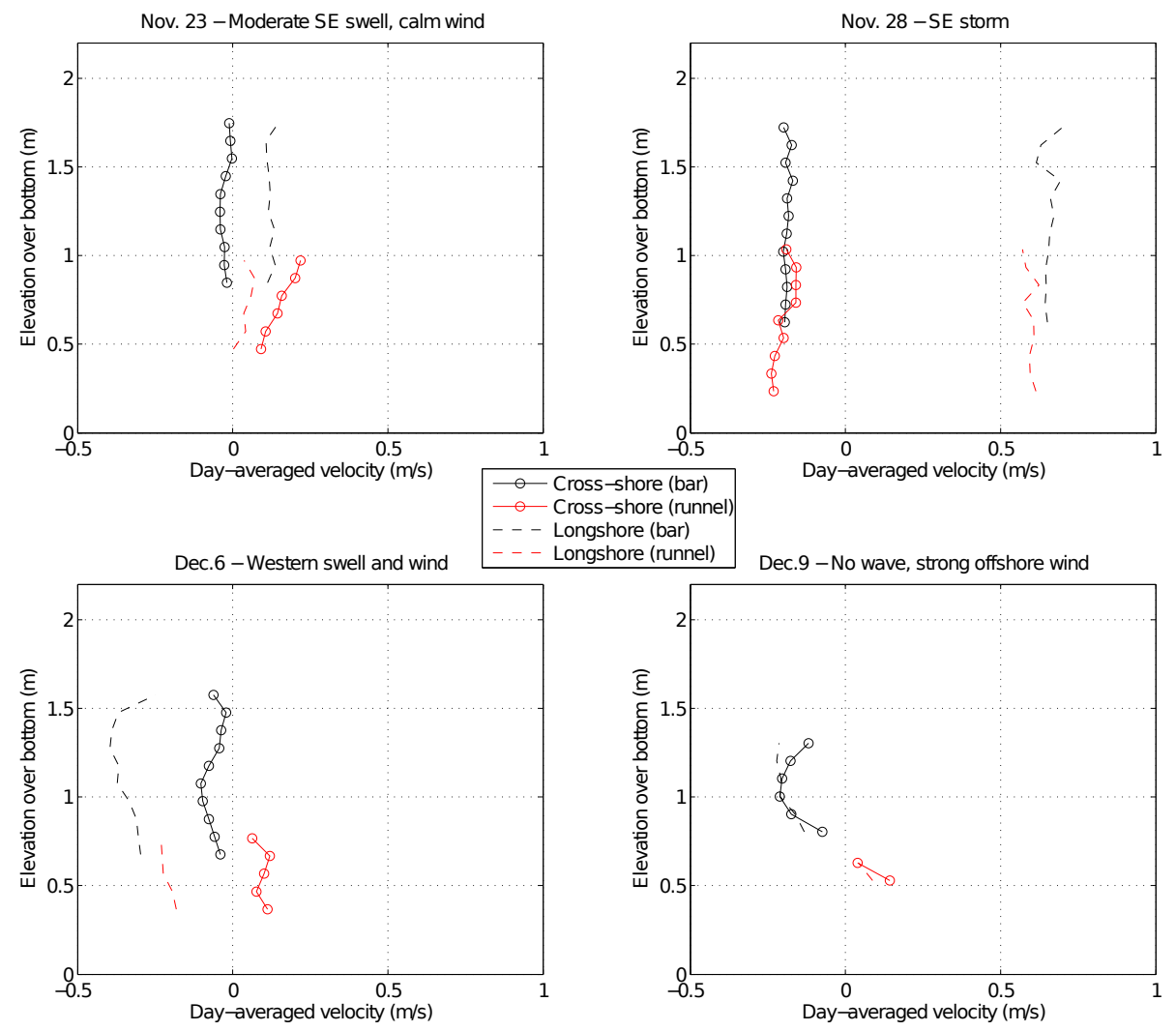

Figure 5: Day-averaged vertical current profiles for four selected dates. Trough and outer bar slope measurements are depicted in red and black respectively.

evolve permanently, vertical elevations are depicted with respect to the bottom. The free surface is generally just above the higher active cell of the profilers. Unfortunately the base of the vertical profiles are scarcely documented as (i) there is a blanking of the first measured cells above the head of the equipments, and (ii) the present experimental setup consisted in the deployment of upside looking profilers a few tens of decimeters above the seabottom.

\section{Moderate incoming South-East swell and calm wind conditions}

The selected day is November 23 (Figs 5 and 6). Waves are moderate $\left(H_{o}=0.65 \mathrm{~m}\right)$ but large enough to induce breaking on the bar. The wind is South-Westerly and weak ( $W=3 \mathrm{~m} / \mathrm{s})$. Over the bar slope (i.e. outside the surf zone), the current is nearly depth-uniform and purely longshore (westward). The tendency is reversed in the trough with a greater cross-shore component and a very weak longshore component. It is positive in the upper half of the water column and vertically sheared. This is in good agreement with the trough current profiles obtained by Haines and Sallenger (1994) but constrats with the field data of Smith et al. (1993b) which has observed a rather uniform vertical profile. In our case, the bar is well developed and shallow while the trough is quite deep. During moderate wave conditions, most of the breaking occurs on the bar. At the measurement point CP4, reformed waves propagate without significant breaking as predicted by the local ratio of the significant wave height over the water depth which is about 0.2 . This value is by far lower than the threshold value 0.59 of Thornton and Guza (1983). It is also noticeable that the classical onshore surface flux is maintained even in the absence of local breaking.

\section{Storm conditions}

On November 28 (Figs 5 and 6), a moderate storm stroke the site, with a day-averaged deep-water wave height about $1.6 \mathrm{~m}$ and onshore South-Easterly wind about $12 \mathrm{~m} / \mathrm{s}$. No bathymetric survey was performed that day; but the seabottom profile should be an intermediate between that measured on Nov. 20 and Dec. 4 (Fig. 2). The bar shifted $30 \mathrm{~m}$ seaward and deepened. Both CP3 and CP4 profilers are in the surf zone, which ends somewhere in the trough. Current structures are very similar at CP3 and CP4. The longshore 

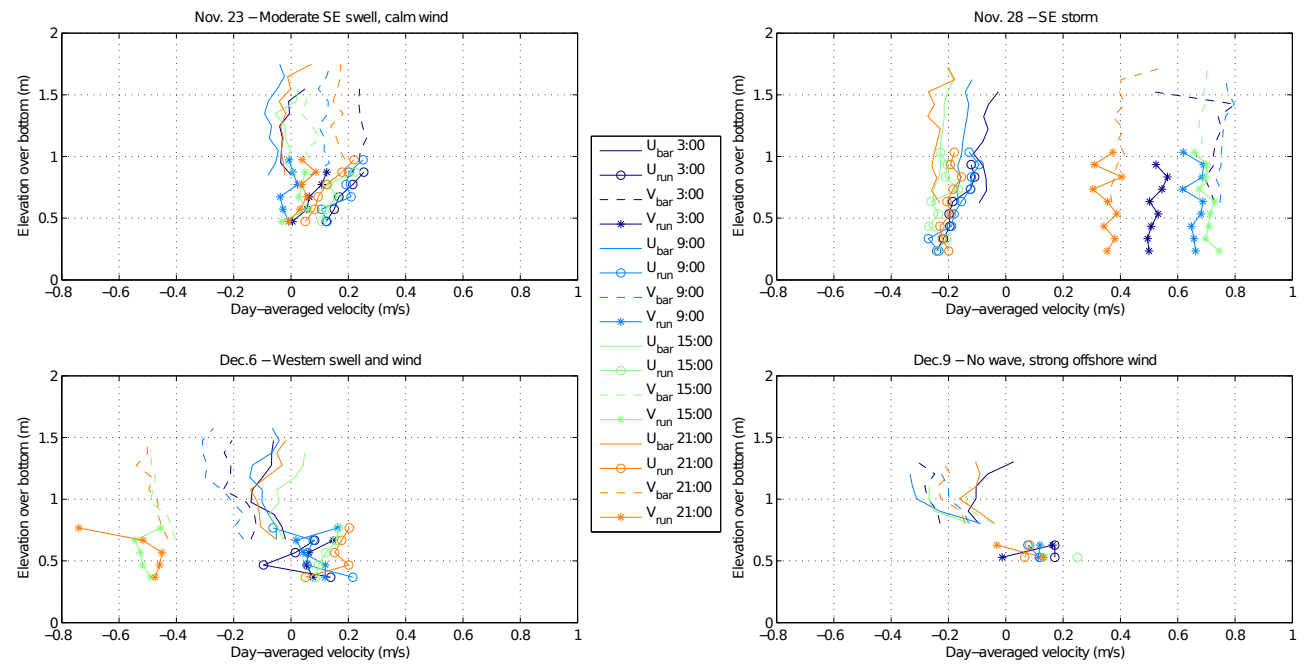

Figure 6: 6h-averaged vertical current profiles for four selected dates. trough and bar slope cross-shore measurements are depicted in non-marked and marked line, respectively.

component is strong $(0.7 \mathrm{~m} / \mathrm{s})$, positive (westward) and vertically uniform. It is stronger on the bar slope than close to the shoreline. This result differs from the observations of Smith et al. (1993a); Thornton et al. (1996); the comparison should be made carefully as our inner measurement point is not in the trough but closer to the shore with respect to the points compared in those studies. Cross-shore component is also uniform, but less intense (about $0.2 \mathrm{~m} / \mathrm{s}$ ) and negative (seaward). Measurements are not available in the upper part of the water column due to the presence of wave breaking, which probably explains why we do not identify the onshore surface flux expected during wave breaking. It is worthwhile to note that, similarly to Haines and Sallenger (1994), the return flow extends on the major part of the water column.

\section{Western swell and wind}

On Dec.6, the incoming wave height is similar to the Nov. 23, but both swell and wind (about $6 \mathrm{~m} / \mathrm{s}$ ) are coming from the West. These conditions are associated with a high-pressure meteorogical system which induces a low mean water level. Cross-shore currents are rather weak and show similar directions as those observed on Nov. 23, i.e. shoreward in the trough and seaward over the bar slope. The small inflection in the vertical profile over the bar reminds the observation of Haines and Sallenger (1994); Reniers et al. (2004). Longshore currents are pushed eastward by the western forcing and show a small nearly linear shear.

\section{No wave and strong offshore wind}

The pattern depicted here corresponds to strong Mistral wind conditions. Day-averaged wave height are less than $0.2 \mathrm{~m}$ while the North-Westerly wind blows up to $16 \mathrm{~m} / \mathrm{s}$. The water level is very low, which give access only to a very small portion of the water column in the trough. One notes however a peculiar pattern, with opposite flows on both sides of the bar. Seaward flow is observed over the bar, which reaches $0.23 \mathrm{~m} / \mathrm{s}$ even in the total absence of wave breaking. The vertical shear appears to be quite strong for each components.

The regime shift from wave-dominated to wind-dominated current structure is detailed for the crossshore component over the bar slope in Fig. 7 for the night of Dec. 8-9. The evolution can be divided in three successive typical phases. First, the initial situation is a vertically uniform slow current as observed previously in the typical situation of Nov. 23. Then, between 2:00 and 5:00 a.m. on Dec. 9, the wind speeds up while the wave forcing remains nearly the same. During this phase, the cross-shore current increases seaward but remains quite vertically uniform. One can hypothesize that the wave motion helps to transfer downward the momentum flux injected by the wind stress at the surface. In the present case, this momentum flux transported throughout the water column is observed in non-breaking conditions, and is very comparable to the observations of Church and Thornton (1993) in wave breaking conditions. Finally, 

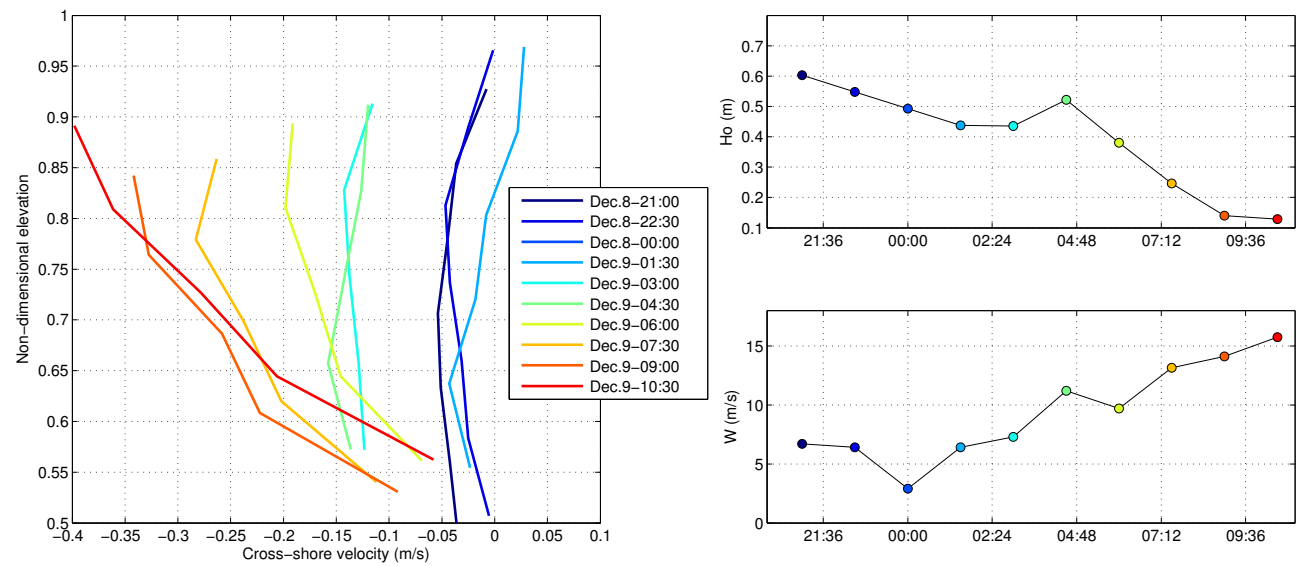

Figure 7: Time evolution of the cross-shore velocity component at CP3 (bar slope) during the shifting of wind conditions on Dec. 9.

from 5:00 a.m., the wave height drops quickly to reach 0.12 $\mathrm{m}$ at 9:00 a.m. while the North-Westerly winds keep increasing, exceeding $15 \mathrm{~m} / \mathrm{s}$. A strong and nearly linear vertical shear develops in the whole water column of the offshore current as it is no longer subjected to the mixing effect of wave orbital motion. This transition reveals the role played by wind and wave interactions on the vertical structure of the current. The development of such a vertical shear will in turn affect wave propagation (Rey et al., 2014).

\section{NEARSHORE CIRCULATION PATTERNS AND PATTERN TRANSITIONS}

Based on the same method as in the examples above, a systematic review of the horizontal and vertical structures of the currents throughout the winter 2014-2015 season at Rousty reveals three typical circulation patterns.

The strongest and most consistent pattern is observed during storms associated with low pressure systems, with wind and wave coming from East or South-East. Measured currents are quite homogeneous along the instrumented cross-shore beach profile. Longshore components are strong and westward while cross-shore components are less intense (nearly one third of their longshore counterparts) and oriented seaward. Both components are vertically uniform over the measured portion of the water column. The circulation is stable through time as long as the forcings remain significant.

As one may expect, the currents are observed to slow down when waves and wind activity from East or South-East decreases. However, the decrease of energy tends to shift the system to a distinct circulation pattern: the currents on both sides of the bar are decoupled. On one hand, the current over the bar slope remains westward with a nearly zero cross-shore component. On the other hand, in the trough, the longshore component can either remains westward or stops. The cross-shore component in the trough is onshore and vertically sheared (strongly at the surface). It is furthermore observed that the lower shoreface current appears to be driven by the continental shelf coastal circulation; thus it is rather disconnected from the bar-trough current system.

In opposite meteo-marine conditions, that is Westerly forcings, the overall circulation is reversed toward the East and form another nearshore circulation pattern. However, over the considered period, the South-West events never reach the intensity of the South-East storms. As a consequence, the decoupled behaviour where inner trough and outer bar circulations evolved quite independantly dominates for such forcing conditions. During calm wind and waves, the nearshore circulation is controlled by the regional current, excepted in the trough where the local breaking of small waves drives current perturbations.

The three typical nearshore circulation patterns presented here are always well-established and perfectly identifiable for period of hours in the time series. However, the shift from one pattern to another (like e.g. on December 9; Fig 3) is abrupt generally. The possible triggering mechanisms must be relative to some thresholds like (i) a sudden compartmentalisation of the trough and outer bar circulations due to a particularly low water level over the sand bar crest, (ii) the occurrence of a critical and complex wave 
refraction/diffraction on top of particularly well-formed outer bars and deep troughs, so that wave-induced currents of alternative directions may develop. The exact reasons why such changes occur suddenly remain speculative at this stage of the analysis.

\section{CONCLUSION}

The ROUSTY2014 experiment provides new insights on the dynamics of microtidal nearshore circulation forced by varying winter meteo-marine forcings. The overall analysis of the time series highlights three main circulation patterns during the winter season, largely controled by the bathymetric features (the occurence of well-formed troughs and sand bars) and by co-working or competing wind and waves forcings. The results suggest a possible sporadic decoupling of the inner trough and outer bar circulations driven by the magnitude of the wind/wave-driven currents.

In all cases, the Rousty experiment provides also a striking set of data relative to the vertical structuration of the current whose interpretation is still on-going. Further developments will concern 3D vertical structuration, instantaneous and mean water level dynamics and possibly comparison and generalization with other existing field experiments.

\section{ACKNOWLEDGEMENTS}

This study was sponsored by the Direction Departementale Territoriale et Maritime 13. We thank the Parc Naturel Régional de Camargue, Reserve Naturelle de Camargue and the municipality of SaintesMaries-de-la-Mer for their technical assistance and for having provided us with the autorization to access the beach. We are grateful to the many contributors involved punctually in the field experiment. Last, the autors would like to thank French ANR and DGA for their financial support of the project MORHOC'H through grant number ANR-13-ASTR-0007. As for most of the field experiments in the northern Mediterranean basin, the group GLADYS (www . gladys-littoral . org) supported the experimentation and the logistics.

\section{References}

J. C. Church and E. B. Thornton. Effects of breaking wave induced turbulence within a longshore current model. Coastal engineering, 20(1-2):1-28, 1993.

D. T. Cox and N. Kobayashi. Application of an undertow model to irregular waves on plane and barred beaches. Journal of coastal research, pages 1314-1324, 1998.

M. Dyhr-Nielsen and T. Sørensen. Some sand transport phenomena on coasts with bars. In Coastal Engineering 1970, pages 855-865. 1970.

A. Faria, E. Thornton, T. Lippmann, and T. Stanton. Undertow over a barred beach. Journal of Geophysical Research: Oceans, 105(C7):16999-17010, 2000.

F. Feddersen and R. Guza. Observations of nearshore circulation: Alongshore uniformity. Journal of Geophysical Research: Oceans, 108(C1), 2003.

B. Greenwood and P. D. Osborne. Vertical and horizontal structure in cross-shore flows: an example of undertow and wave set-up on a barred beach. Coastal Engineering, 14(6):543-580, 1990.

J. W. Haines and A. H. Sallenger. Vertical structure of mean cross-shore currents across a barred surf zone. Journal of Geophysical Research: Oceans, 99(C7):14223-14242, 1994.

J. B. Hansen and I. Svendsen. A theoretical and experimental study of undertow. In Coastal Engineering 1984, pages 2246-2262. 1985.

M. Larson and N. C. Kraus. Numerical model of longshore current for bar and trough beaches. Journal of Waterway, Port, Coastal, and Ocean Engineering, 117(4):326-347, 1991.

Y. Leredde, C. Denamiel, E. Brambilla, C. Lauer-Leredde, F. Bouchette, and P. Marsaleix. Hydrodynamics in the gulf of aigues-mortes, nw mediterranean sea: In situ and modelling data. Continental Shelf Research, 27(18):2389-2406, 2007.

M. S. Longuet-Higgins. Longshore currents generated by obliquely incident sea waves: 1. Journal of geophysical research, 75(33):6778-6789, 1970. 
A. Okayasu, T. Shibayama, and K. Horikawa. Vertical variation of undertow in the surf zone. In Coastal Engineering 1988, pages 478-491. 1989.

J. O'Rourke and P. LeBlond. Longshore currents in a semicircular bay. Journal of Geophysical Research, 77(3):444-452, 1972.

A. Ouahsine, H. Smaoui, K. Meftah, P. Sergent, and F. Sabatier. Numerical study of coastal sandbar migration, by hydro-morphodynamical coupling. Environ. Fluid. Mech., 13:169-187, 2013.

A. Petrenko. Variability of circulation features in the gulf of lion nw mediterranean sea. importance of inertial currents. Oceanologica Acta, 26(4):323-338, 2003.

A. Petrenko, Y. Leredde, and P. Marsaleix. Circulation in a stratified and wind-forced gulf of lions, nw mediterranean sea: in situ and modeling data. Continental Shelf Research, 25(1):7-27, 2005.

U. Putrevu and I. A. Svendsen. Vertical structure of the undertow outside the surf zone. Journal of Geophysical Research: Oceans, 98(C12):22707-22716, 1993.

A. Reniers, E. Thornton, T. Stanton, and J. Roelvink. Vertical flow structure during sandy duck: observations and modeling. Coastal Engineering, 51(3):237-260, 2004.

V. Rey, J. Charland, and J. Touboul. Wave-current interaction in the presence of a three-dimensional bathymetry: Deep water wave focusing in opposing current conditions. Physics of Fluids, 26(9):096601, 2014.

F. Sabatier. Fonctionnement et dynamiques morpho-sédimentaires du littoral du delta du Rhône. PhD thesis, Université d'Aix-Marseille III, 2001.

F. Sabatier. Modélisation de l'impact du changement climatique sur l'érosion des dunes. application à la camargue. La Houille Blanche, (1):40-49, 2008.

F. Sabatier, E. J. Anthony, A. Héquette, S. Suanez, J. Musereau, M.-H. Ruz, and H. Régnauld. Morphodynamics of beach/dune systems: examples from the coast of france. Géomorphologie: relief, processus, environnement, (1/2009):3-22, 2009a.

F. Sabatier, O. Samat, A. Ullmann, and S. Suanez. Connecting large-scale coastal behaviour with coastal management of the rhône delta. Geomorphology, 107(1):79-89, 2009 b.

J. M. Smith, M. Larson, and N. C. Kraus. Longshore current on a barred beach: Field measurements and calculation. Journal of Geophysical Research: Oceans, 98(C12):22717-22731, 1993a.

J. M. Smith, I. A. Svendsen, and U. Putrevu. Vertical structure of the nearshore current at delilah: Measured and modeled. In Coastal Engineering 1992, pages 2825-2838. 1993 b.

M. Stive and H. Wind. Cross-shore mean flow in the surf zone. Coastal Engineering, 10(4):325-340, 1986.

E. Thornton, R. Humiston, and W. Birkemeier. Bar/trough generation on a natural beach. Journal of Geophysical Research: Oceans, 101(C5):12097-12110, 1996.

E. B. Thornton. Variation of longshore current across the surf zone. In Coastal Engineering 1970, pages 291-308. 1970.

E. B. Thornton and R. Guza. Transformation of wave height distribution. Journal of Geophysical Research: Oceans, 88(C10):5925-5938, 1983.

E. B. Thornton and R. T. Guza. Surf zone longshore currents and random waves: Field data and models. Journal of Physical Oceanography, 16(7):1165-1178, 1986.

F. C. Ting and J. T. Kirby. Observation of undertow and turbulence in a laboratory surf zone. Coastal Engineering, 24(1-2):51-80, 1994.

D. J. Whitford and E. B. Thornton. Comparison of wind and wave forcing of longshore currents. Continental Shelf Research, 13(11):1205-1218, 1993. 